\title{
Root Pruning and Stability of Young Willow Oak
}

\author{
E. Thomas Smiley
}

\begin{abstract}
Two root-pruning methods simulated construction-related trenching and individual root cuts such as from decay after root pruning. Tree trunks were pulled to an angle of $1^{\circ}$ from vertical using measured force. A third of the study trees were pulled to failure to determine the relationship between the $1^{\circ}$ pull force and the pull-to-failure force. The regression had correlation with $\mathrm{r}^{2}$ equal to 0.76 . Utility trenching was simulated with linear cuts across the root zone. Measurable decreases in force applied occurred when cuts were within three times the trunk diameter from the trunk. Force decreased by $35 \%$ when a tangential cut was made at the trunk. When individual roots were severed, the pull force was reduced with each root cut. When one root was severed, the decrease in force averaged $12 \%$; when half of the exposed buttress roots were severed, the decrease was $30 \%$. Arborists should avoid cutting any tree roots near the trunk. Linear trenching should not be closer to the trunk than a distance equal to or greater than three times the trunk diameter.
\end{abstract}

Key Words. Construction damage; pull testing; root anchorage; root barrier; root decay; root plate; utility trenching; windthrow.

Root systems are a key component in tree stability. Roots must have the strength to withstand the force of wind without breaking or uprooting (Coutts 1983; Mattheck et al. 1997; Harris et al. 2004). When roots are decayed, cut, or damaged, tree stability and health may be reduced (Matheny and Clark 1994; Hamilton 1998). The threshold point at which root damage increases the risk of tree failure has not been well studied.

According to the International Tree Failure Database, $35 \%$ of reported tree failures are root-related (ITFD 2007). Root failure patterns vary with tree species, size, age, and soil conditions (Mattheck et al. 1997; Stokes 1999; Mickovski and Ennos 2003; Dupuy et al. 2005b). Genet et al. (2005) found significant differences in root strength among tree species with Fagus sylvatica $>$ Picea abies $>$ Castanea sativa $>$ Pinus pinaster $\simeq$ Pinus nigra. They also found that root tensile strength was higher in smaller diameter roots.

Root system morphology is a function of species characteristics and soil conditions (Busgen et al. 1929; Stokes and Mattheck 1996). Tree anchorage depends on root system morphology and soil type (Ennos 1993; Stokes et al. 1996; Stokes and Mattheck 1996). Stokes (1999) found that 13-year-old pines tended to fail either at the base of the trunk or at the tap root, whereas 17year-old pines failed at the tap root or lateral roots. Anchorage strength was found to be proportional to trunk diameter in several studies (Stokes 1999; Mickovski and Ennos 2003).

In studies of stability of green ash (Fraxinus pennsylvanica), roots broke in different locations dependent on soil moisture levels and root configuration (Smiley et al. 2000). When trees were pulled to failure in wet soil (33\% water, w/w), either smaller roots failed or intact roots pulled out of the soil. When the soil was drier (13\% water), roots tended to break in the larger diameter classes located near the trunk. In both soil moisture conditions, deeper-rooted trees were more resistant to failure than the shallow-rooted trees. This has also been demonstrated using tree root models (Stokes et al. 1996). Looking at soil failures associated with wet soil, Coutts (1983) concluded that the components of tree anchorage included the size and weight of the root plate, strength of the roots and soil, and the fulcrum force of leeward roots.
In a survey of fallen and standing trees after hurricane force winds, Smiley et al. (1998) proposed a method of evaluating the effects of decay on tree roots. Results of this study concluded that tree stability was dependent on both the amount of decay in individual roots and the number of roots that were decayed. Dupuy et al. (2005a) also concluded that the number and diameter of roots affected the resistance to tree uprooting.

Trenching near the tree trunk has been shown to significantly reduce the force required to cause tree failure (Hamilton 1988; O'Sullivan and Ritchie 1993). Fraedrich and Smiley et al. (2002) proposed limits to trenching near the trunk: no closer than three times the trunk diameter. When Watson (1988) cut roots at this distance, however, a significant reduction in health was not detected until roots on three or four sides of the tree were cut. Miller and Neely (1993) found reductions in tree growth only when linear trenches were closer than three times the trunk diameter.

Forest tree research on stability has focused on pulling trunks or tall stumps to the point of failure (Coutts 1983; Crook and Ennos 1996; Mickovski and Ennos 2002, 2003). An alternative method of is the static pull test (Brudi and van Wassenaer 2002). Tension is applied to an intact tree using a cable, dynamometer, and winch and the angle of trunk lean is measured. This method requires less force and does not destroy the tree, so the same tree can be tested multiple times.

The purpose of this study was to examine two types of root cutting and determine the impact of root severance on tree stability. These root-cutting methods were intended to simulate construction-related trenching and individual root cutting.

\section{MATERIALS AND METHODS}

On 8 November 2000, 30 willow oaks (Quercus phellos) were planted in two rows $4.6 \mathrm{~m}(15.2 \mathrm{ft})$ apart and $7.6 \mathrm{~m}(25.1 \mathrm{ft})$ between rows. Soil was a moderately well-drained Cecil sandy clay loam (CeB2, thermic typic hapludults). At planting, the balled-and-burlapped trees were $5 \mathrm{~cm}$ (2 in) caliper. Sprinkler irrigation was applied during drought periods and 30N-7P-9K slow-release fertilizer was applied on an annual basis. All trees were mulched annually with fresh wood chips. Weed growth was 
managed with glyphosate herbicide. Trees were not staked or guyed.

Various root barriers were at the time of planting $60 \mathrm{~cm}(24$ in) from the trunk (Smiley 2005). The root barriers affected root growth at the root barriers, causing the roots to grow deeper in the soil. This was not thought to affect results as a result of the distance from the trunk and direction of the pull force applied.

Trees were pull-tested between 25 and 30 January 2007. At the time of testing, tree height, diameter at $1.4 \mathrm{~m}(4.6 \mathrm{ft}$, diameter at breast height [dbh]), caliper at $15 \mathrm{~cm}$ (6 in), and branch spread perpendicular to the pull angle were measured. Branches below $1.4 \mathrm{~m}(4.6 \mathrm{ft})$ were removed from all trees to facilitate trunk access.

Two $5 \mathrm{~cm}$ ( 2 in) roofing nails were driven into the trunk xylem 15 and $75 \mathrm{~cm}$ (6 and $30 \mathrm{in}$ ) above grade (Figure 1). The nail at $75 \mathrm{~cm}$ (30 in) was installed directly above the nail driven at 15 $\mathrm{cm}$ (6 in). Nail depth was adjusted at the beginning of the experiment using a digital level (Smart Level; Maryland Building Products, Oklahoma City, OK, U.S.) to read $90^{\circ}\left( \pm 0.05^{\circ}\right)$.

A dynamometer (Dillon ED-200+, Fairmont, MN) was attached to the trunk of the subject tree $1.4 \mathrm{~m}(4.6 \mathrm{ft})$ above grade using a webbing sling. A low stretch line or steel cable was run horizontally to a redirecting pulley on the next tree in the row. The line or cable was then connected to an anchor tree or truck. A 4-to-1 rope pulley system was used to pull the trees to an angle of $89^{\circ}$ ( $1^{\circ}$ of trunk lean). A hand-operated mechanical winch was used to pull to the point of failure. The peak dynamometer reading was recorded for both $1^{\circ}$ pull and pull-to-failure. Failure was defined by the point at which peak force was followed by a drop in the pull force.

The first three trees tested were pulled so that the trunk achieved a maximum angle of $1^{\circ}$ from vertical. Force was released after each pull and the tree trunk returned to vertical; this was repeated seven times. There was no significant difference between the first and the seventh pull force so it was determined that the force to pull the trunk to an angle of $1^{\circ}$ was within the elastic range of the trunk, that is, no permanent structural changes occurred within this pull range. For all subsequent measurements, trees were pulled to $1^{\circ}$ and then released three times. An average of the three peak readings was recorded and used for analysis. This procedure was defined as a "pull test."

Trees were randomized and three different treatments were applied. The first group of eight oaks was pull-tested to $1^{\circ}$ without root damage and then pulled to failure.

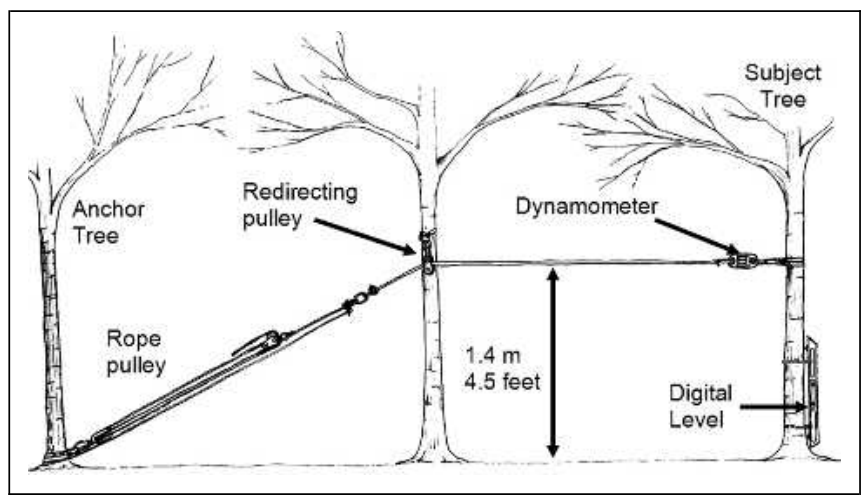

Figure 1. Diagrammatic representation of the pull-testing setup.

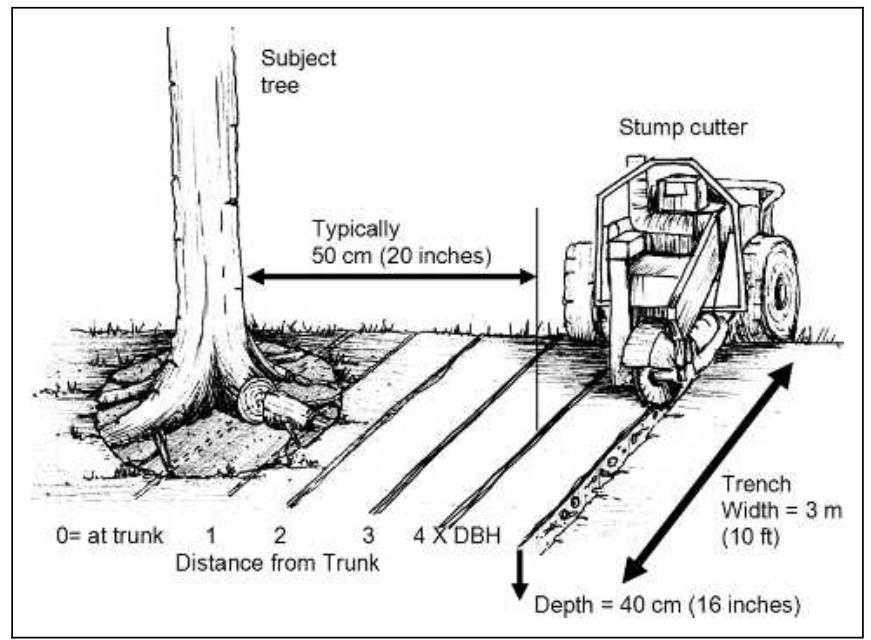

Figure 2. Linear cuts were made with a stump grinder starting at a distance equal to five times the trunk diameter. The trencher was moved closer to the trunk in distance increments equal to the trunk diameter ending with a cut tangential to the trunk.

The second group of 11 trees was pull-tested to $1^{\circ}$ and then a linear root cut was made at a distance of five times the diameter of the trunk away from the base of the tree (Figure 2). Trenches were made with a stump-cutting machine $3 \mathrm{~m}(9.9 \mathrm{ft})$ long and $40 \mathrm{~cm}$ (16 in) deep. After the cut, the tree was again pull-tested. This distance was repeated for three trees, but was then discontinued because there were no significant differences between these force measurements and pretreatment pull force. The rootcutting and pull-testing procedure was repeated with linear cuts at four, three, two, and one times the diameter distances from the trunk. The final cut was at the tree trunk removing a small portion of the trunk and the entire buttress root(s).

The third group of ten trees was partially excavated at the base using a supersonic air tool (Air Spade ${ }^{\mathrm{TM}}$; Concept Engineering Group, Pittsburgh, PA) to expose the buttress roots. A count of all visible buttress roots was made and the initial pull test was conducted. A root directly opposite the pull line was severed at two points and a section of the root was removed, removing any

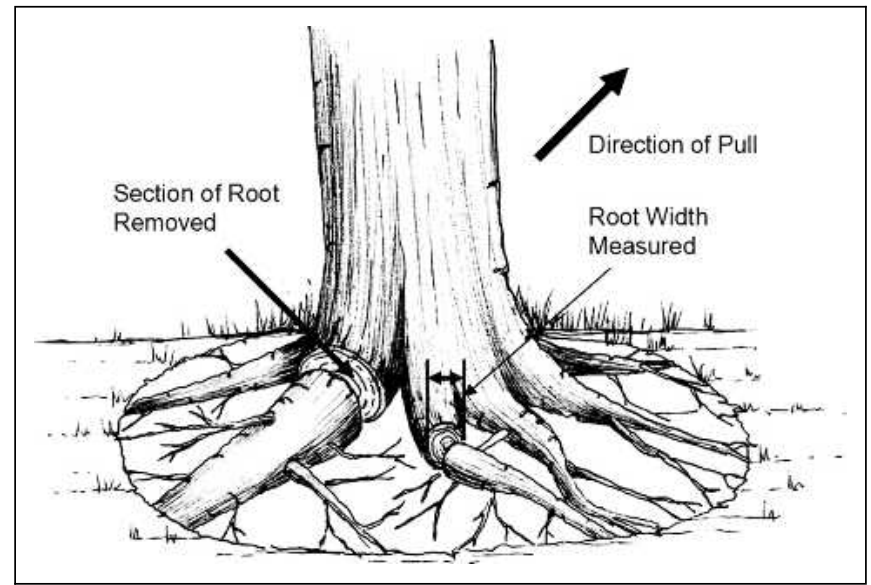

Figure 3. Roots in Group 3 trees were severed one at a time starting opposite the pull line and alternating right and left until all of the roots on $50 \%$ of the circumference were severed and a section removed. 
Table 1. Dimensions of willow oak trees tested.

\begin{tabular}{|c|c|c|c|c|c|c|}
\hline \multirow[b]{3}{*}{ Parameter } & \multicolumn{2}{|c|}{ Group 1} & \multicolumn{2}{|c|}{ Group 2} & \multicolumn{2}{|c|}{ Group 3} \\
\hline & \multicolumn{2}{|c|}{ Pulled to failure } & \multicolumn{2}{|c|}{ Linear root cut } & \multicolumn{2}{|c|}{ Individual cuts } \\
\hline & Mean & $\begin{array}{l}\text { Standard } \\
\text { deviation }\end{array}$ & Mean & $\begin{array}{l}\text { Standard } \\
\text { deviation }\end{array}$ & Mean & $\begin{array}{l}\text { Standard } \\
\text { deviation }\end{array}$ \\
\hline $\mathrm{dbh}$ at $1.4 \mathrm{~m} \mathrm{(}(4.6 \mathrm{ft})$ & $12.6 \mathrm{~cm}(5 \mathrm{in})$ & 1.2 & $12.2 \mathrm{~cm}$ (4.9 in) & 1.9 & $13.6 \mathrm{~cm}(5.4 \mathrm{in})$ & 1.4 \\
\hline Caliper at $15 \mathrm{~cm}(6 \mathrm{in})$ & $16.5 \mathrm{~cm}(6.6 \mathrm{in})$ & 1.3 & $15.8 \mathrm{~cm}(6.3 \mathrm{in})$ & 2.1 & $17.9 \mathrm{~cm}(7.2 \mathrm{in})$ & 1.8 \\
\hline Height & $7.3 \mathrm{~m}(24.1 \mathrm{ft})$ & 0.8 & $7.2 \mathrm{~m}(23.8 \mathrm{ft})$ & 0.4 & $6.8 \mathrm{~m}(22.4 \mathrm{ft})$ & 0.6 \\
\hline Branch spread & $4.6 \mathrm{~m}(15.2 \mathrm{ft})$ & 0.5 & $4.9 \mathrm{~m}(16.2 \mathrm{ft})$ & 0.5 & $4.5 \mathrm{~m}(14.9 \mathrm{ft})$ & 0.6 \\
\hline Number of trees & 8 & & 11 & & 10 & \\
\hline
\end{tabular}

$\mathrm{dbh}=$ diameter at breast height.

connection between the trunk and root (Figure 3). The horizontal width of the severed root section was measured. The tree was again pulled to $1^{\circ}$. This procedure was repeated with cutting roots on alternating sides of the first root cut until roots were severed from $50 \%$ of the root flare circumference. A comparison of the reduction in force required to pull the trunk to an angle of $1^{\circ}$ was made both with the percentage of roots ( $\%$ of roots cut $=$ number of roots cut/total number of roots) that were cut and the cross-sectional area factor (root area factor $=$ sum of width of roots/trunk diameter) of the roots that were cut.

Pull force measurements were standardized to remove the influence of trunk diameter by dividing the peak force to move the trunk $1^{\circ}$ after root cutting by the peak force before cutting any roots and multiplying by 100 . Correlation coefficients, paired sample t-tests, and regression analyses were conducted on the data using SPSS (SPSS Inc., Chicago, IL). For linear root cuts, standardized force means were compared with $4 \times \mathrm{dbh}$ using paired sample t-test $(P=0.05)$.

\section{RESULTS}

At the time of pull testing, mean trunk diameter at $1.4 \mathrm{~m}(4.6 \mathrm{ft})$ was $12.8 \mathrm{~cm}$ (5.1 in) (Table 1). Soil moisture level at the time of testing was $20 \%(\mathrm{w} / \mathrm{w})$.

When trees were pulled to the point of failure, roots were heard splitting below grade near the trunk, soil lifted on several trees on the side opposite of the pull, and few roots pulled out of the ground. No trunk breakage occurred. Trunk angle at the point of failure was typically $35^{\circ}$. In the pulling-to-failure trial (Group $1)$, there was a highly significant $(P=0.005)$ correlation $\left(\mathrm{r}^{2}=\right.$ $0.76)$ between the $1^{\circ}$ pull and the peak force at the point of failure (Figure 4).

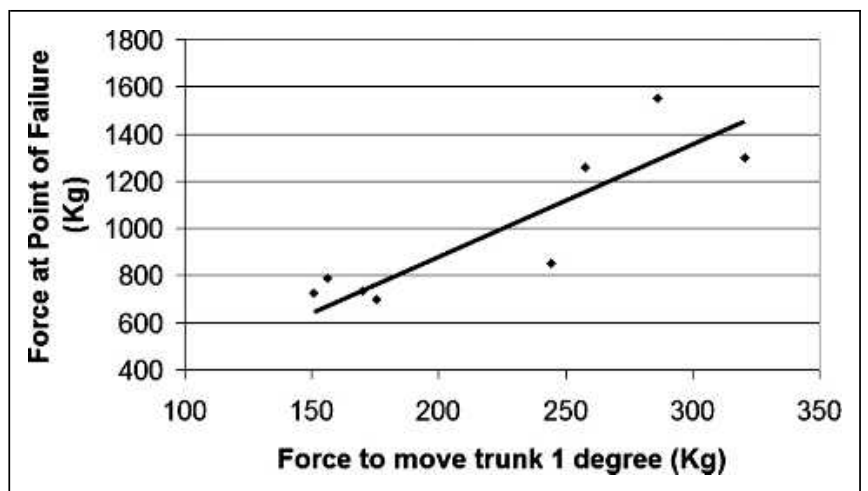

Figure 4. Correlation between the force required to pull the trunk to an angle of $1^{\circ}$ and the force required to pull the tree to the point of failure $\left(F_{\text {Failure }}=4.35\left(F_{1}\right)+27 ; r^{2}=0.76\right.$.
Linear root severance caused no significant reduction in the force required to move the trunk $1^{\circ}$ until cuts were closer than three times the trunk diameter (Figure 5). At two times the trunk diameter, the force was reduced $15 \%$. At a distance from the trunk equal to the trunk diameter, the force was reduced approximately $23 \%$ and when cut tangential to the trunk, the force was reduced by $35 \%$. At all root-cutting distances, there were highly significant relationships $\left(r^{2}=0.76\right.$ to 0.84$)$ between pull force and trunk diameter; the larger the diameter, the greater the force required to move the trunk (Table 2).

All of the trees subjected to individual root removal had seven to nine buttress roots, so each root removed corresponded to $11 \%$ to $14 \%$ of the buttress roots. A comparison of the reduction in force required to pull the trunk to an angle of $1^{\circ}$ was made both with the percentage of roots cut and the cross-sectional area removed (Figures 6 and 7). The $r^{2}$ value was higher with the percent-of-roots-cut method $\left(\mathrm{r}^{2}=0.80\right)$ as compared with the area method $\left(r^{2}=0.64\right)$. Typically, there was a $15 \%$ to $25 \%$ variation in the force measurements using the percent-of-rootscut method. The variation in force was greater with the width method. When the first root was cut, the force was reduced by $12 \%$. When $50 \%$ of the roots were cut, the average force reduction was $30 \%$. In one case, $90 \%$ of the tree's buttress roots arose

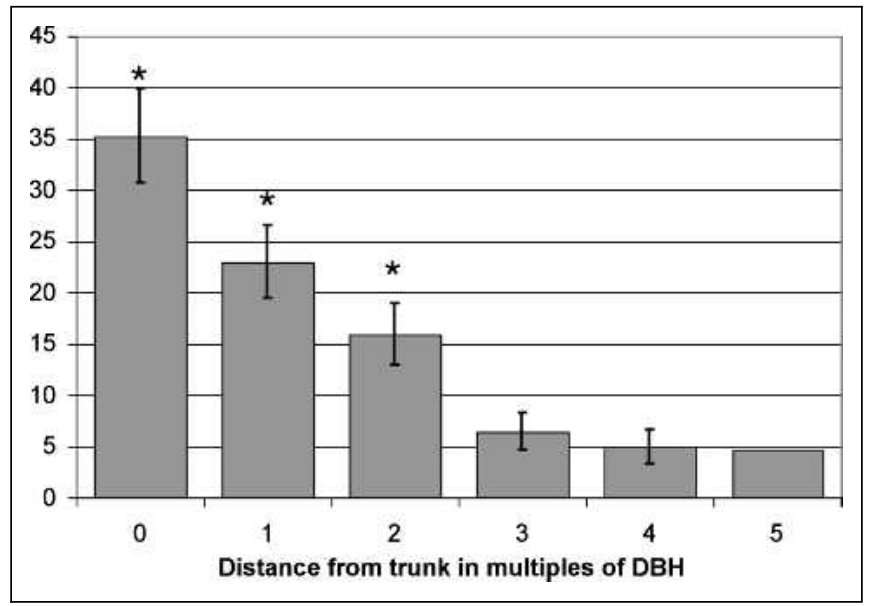

Figure 5. Standardized force to move the trunk $1^{\circ}$ compared with the distance from the trunk of the linear root cuts. Each point is an average of 11 pull tests with the exception of the $5 \times$ diameter at breast height ( $\mathrm{dbh}$ ), which is the average of three pull tests. Asterisk indicates that a significant difference exists $(P=0.05)$ with the $4 \times \mathrm{dbh}$ value using paired sample t-tests. 
Table 2. Mean reduction in pull force compared with linear root cutting at different distances from the trunk.

\begin{tabular}{lll}
\hline Distance & Regression & $\mathrm{r}^{2}$ \\
\hline No cuts & $\mathrm{F}_{1}=75(\mathrm{dbh})-710$ & 0.78 \\
Four & $\mathrm{F}_{1}=65(\mathrm{dbh})-580$ & 0.76 \\
Three & $\mathrm{F}_{1}=80(\mathrm{dbh})-790$ & 0.81 \\
Two & $\mathrm{F}_{1}=80(\mathrm{dbh})-820$ & 0.84 \\
One & $\mathrm{F}_{1}=66(\mathrm{dbh})-660$ & 0.84 \\
Zero & $\mathrm{F}_{1}=75(\mathrm{dbh})-800$ & 0.81
\end{tabular}

dbh multiples where $\mathrm{F}_{1}=$ force to pull trunk $1^{\circ}$ in kilograms and dbh $=$ diameter at $1.4 \mathrm{~m}(4.6 \mathrm{ft})$ in centimeters.

from $50 \%$ of the tree's root collar circumference and were cut off. This resulted in greater than a $50 \%$ reduction in force.

\section{DISCUSSION}

Force to pull willow oaks to a trunk angle of $1^{\circ}$ correlated well with the force required to pull the trees to failure. This is consistent with Brudi and van Wassenaer (2002). The strength of this relationship allowed us to translate the subsequent $1^{\circ}$ pulltesting data to failure with some degree of certainty.

The effects of cutting individual roots on tree stability are highly variable. Cutting one root (10\% to $15 \%$ of buttress roots) may have little impact on tree stability or it may reduce the force required to cause failure by more than $20 \%$ (Figure 6). When $30 \%$ of the roots (three of nine buttress roots) are severed, the force required to cause failure is reduced by approximately $20 \%$; however, on some trees, this number was over $30 \%$. When $50 \%$ of the roots were cut off, force was reduced on average by one-third.

When comparing two methods of assessing the amount of root loss, percentage-of-roots-cut (Figure 6) or area-of-roots-cut (Figure 7), this study found less variability when using the percentage-of-roots-cut method. Although this does simplify root assessment, results may be different if root width is highly variable on an individual tree.

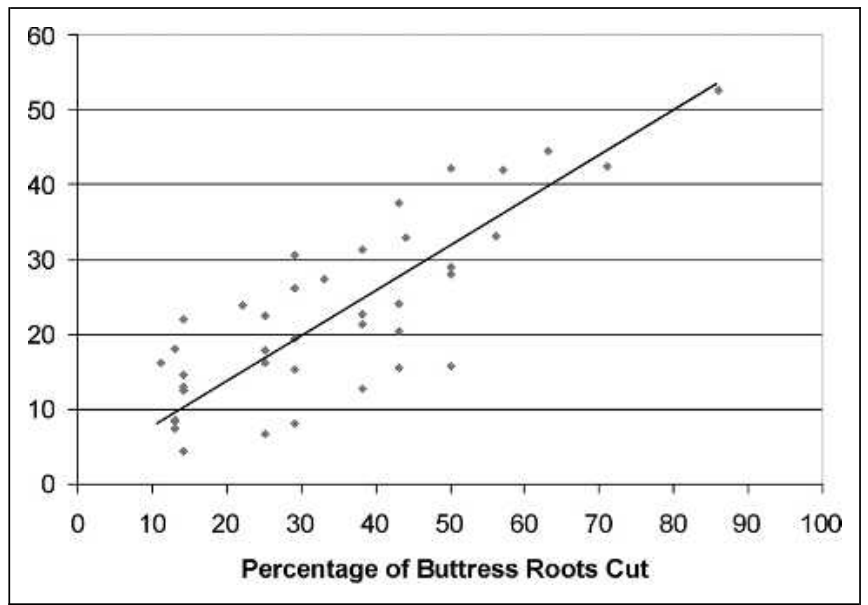

Figure 6. Comparison of the percentage of buttress roots cut $\left(R_{\text {cut }} / R_{\text {Total }} \times 100\right)$ and the standardized force $\left(F_{\text {Std }}=\right.$ peak force to move the trunk $1^{\circ}$ after root cutting divided by the peak force before cutting roots multiplied by 100 ) to move the trunk $1^{\circ} . \mathrm{F}_{\mathrm{Std}}=1.99+0.59\left(\mathrm{R}_{\text {cut }} / \mathrm{R}_{\text {Total }} \times 100\right), \mathrm{r}^{2}=0.80$.

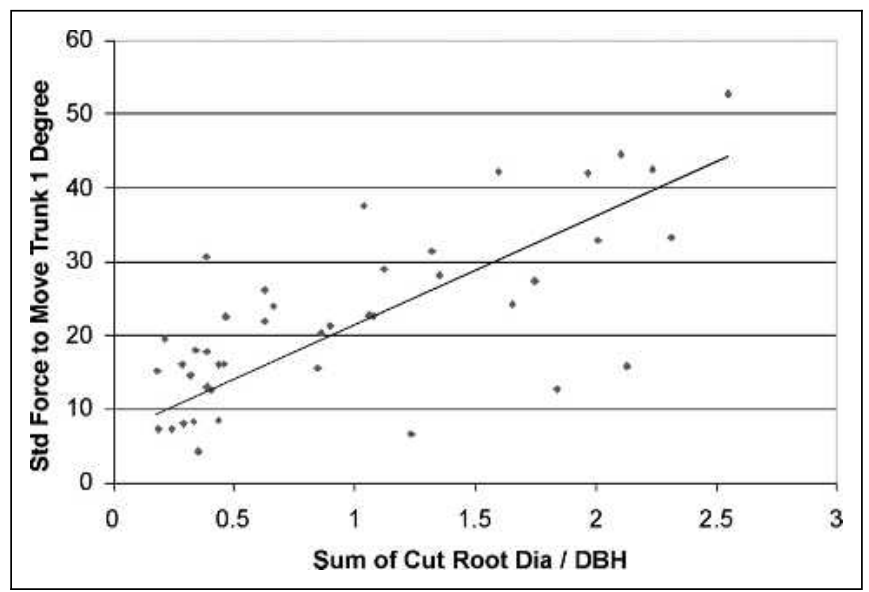

Figure 7. The sum of diameters of all roots that were severed divided by $\mathrm{dbh}\left(\sum \mathrm{R}_{\text {cut dia }} / \mathrm{dbh} \times 100\right)$ compared with the standardized force $\left(F_{\text {std }}=\right.$ peak force to move the trunk $1^{\circ}$ after root cutting divided by the peak force before cutting roots multiplied by 100 ) to move the trunk $1^{\circ}$. $\mathrm{F}_{\mathrm{Std}}=6.49+15$ $\left(\Sigma R_{\text {cut dia }} / \mathrm{dbh} \times 100\right), \mathrm{r}^{2}=0.64 . \mathrm{dbh}=$ diameter at breast height.

Force reduction numbers were lower than expected. This may reflect the influence of uncut deep roots (heart roots, oblique roots) that develop on many species of trees. Working in conjunction with the buttress roots, deep roots play an important role in tree stability on small trees (Stokes and Mattheck 1996). This has previously been demonstrated with tap and sinker roots, which provide a major portion of the anchorage strength on some species, especially pines (Mickovski and Ennos 2002; Dupuy et al. 2005b). Larger-diameter mature angiosperms often do not have deep roots or tap roots as a result of species genetics, root decay, or soil depth limitation; thus, larger trees may be more susceptible to damage from lateral root cutting than the smaller trees (pers. obs.).

As a result of the variability in these data on individual root cuts, a general rule as to the maximum percentage of roots that can be cut cannot be stated at this time. Cutting any roots at the trunk may increase the risk of premature tree failure. Roots on the uphill side of a tree, those on the side opposite of a trunk lean, or a large individual root may be more important for tree stability than their individual percentage that the root system reflects (Smiley et al. 2002).

Linear root cuts similar to those made while utility trenching had a higher correlation with force than the individual root cuts. When the trench line was closer than three times the trunk diameter, there was a significant change in the force required to move the trunk. Therefore, cutting roots closer than three times the trunk diameter should not be recommended. That understood, it is surprising that when linear cuts were made at the trunk, the average force reduction was only $35 \%$. Mattheck and Breloer (1994) suggest that trees have a "safety factor" of 5, indicating that trees develop stronger than necessary structure so as not to fail under high winds. In the case of small tree roots, the mechanism is very likely the oblique root system (Stokes and Mattheck 1996). This smaller-than-expected reduction in force may explain why so many trees survive root cutting at the trunk during sidewalk repair operations. Tree species also plays a very important role when linear cuts are made close to the trunk; 
many species cannot tolerate cutting close to the trunk (Hamilton 1998).

A one-third reduction in force was found with $50 \%$ root removal and a linear tangential root cut at the trunk. This may indicate that trenching tends to cut more of the oblique roots and that roots directly opposite the force are far more important to stability than those perpendicular to the direction of force. Under dynamic wind conditions, in which wind intensity and direction may change rapidly, the impact of $50 \%$ root removal would be expected to be greater than a one-sided linear root cut near the trunk. The dynamic osculation of the wind forces are known to cause a progressive failure at lower wind velocities (O'Sullivan and Ritchie 1993; James et al. 2006)

Cutting large-diameter roots may make the root more susceptible to root decay. The maximum size root that can be cut that will not readily decay has yet to be determined. It is possible that cutting roots at a distance of three times the trunk diameter makes the roots more susceptible to decay than cutting roots at a greater distance. Therefore, to be safe when linear root cuts are made, cuts should be at the greatest distance possible from the trunk.

Caution should be exercised in extrapolating these findings to large trees in urban areas. These results are only on one species and the trees were relatively small. More research is needed to see if the conclusions presented here will hold up for other species and larger trees. More information is also needed on the forces that wind exerts on the tree so that pull forces could be correlated with wind speed.

Acknowledgments. Thanks to Robert A. Bartlett Jr. and the F.A. Bartlett Tree Expert Co. for their continuing support of tree care research and Dr. Bruce Fraedrich, Director of the Bartlett Tree Research Laboratories. For conducting these experiments: Liza Wilkinson, Research Technician; Richard Herfurth, Safety and Training Coordinator Hookset NH; Drew Zwart, Plant Diagnostician; Eric Honeycutt, Manager Plant Diagnostic Laboratory, Bartlett Tree Research Lab. Technical assistance from Dr. Brian Kane, University of Massachusetts and manuscript editing by Dr. Jim Clark, HortScience. Drawings by Renee Byrd, Clemson University.

\section{LITERATURE CITED}

Brudi, E., and P. van Wassenaer. 2002. Trees and statics: Nondestructive failure analysis. In Smiley, E.T., and K.D. Coder (Eds.). Tree Structure and Mechanics Conference Proceedings. International Society of Arboriculture, Champaign, IL. 184 pp.

Busgen, M., E. Munch, and T. Thomas. 1929. The Structure and Life of Forest Trees. Chapman and Hall, London, U.K.

Coutts, M.P. 1983. Root architecture and tree stability. Plant and Soil 71:171-188.

Crook, M.J., and A.R. Ennos. 1996. The anchorage mechanics of deep rooted larch, Larix europea $\times$ L. japonica. Journal of Experimental Botany 47:1509-1517.

Dupuy, L., T. Fourcaud, and A. Stokes. 2005a. A numerical investigation into factors affecting the anchorage of roots in tension. European Journal of Soil Science 56:319-327.

- 2005b. A numerical investigation into the influence of soil type and root architecture on tree anchorage. Plant and Soil 278:119-134.

Ennos, A.R. 1993. The scaling of root anchorage. Journal of Theoretical Biology 161:61-75.

Fraedrich, B.R., and E.T. Smiley. 2002. Assessing the failure potential of tree roots. In Smiley, E.T., and K.D. Coder (Eds.). Tree Structure and Mechanics Conference Proceedings. International Society of Arboriculture, Champaign, IL. 184 pp.
Genet, M., A. Stokes, F. Salin, S.B. Mickovski, T. Fourcaud, J.F. Dumail, and R. van Beek. 2005. The influence of cellulose content on tensile strength in tree roots. Plant and Soil 278:1-9.

Hamilton, W.D. 1988. Significance of root severance on performance of established trees. Journal of Arboriculture 14:288-292.

Harris, R.W., J.R. Clark, and N.P. Matheny. 2004. Arboriculture Integrated Management of Landscape Trees, Shrubs and Vines. Prentice Hall, Upper Saddle River, NJ. 580 pp.

ITFD. 2007. International Tree Failure Database web site. http:// ftcweb.fs.fed.us/natfdb/reports.aspx (accessed 4/3/2007).

James, K.R., N. Haritos, and P.K. Ades. 2006. Mechanical stability of trees under dynamic loads. American Journal of Botany 93: 1361-1369.

Matheny, N.P., and J.R. Clark. 1994. A Photographic Guide to the Evaluation of Hazard Trees in Urban Areas. International Society of Arboriculture, Champaign, IL. 85 pp.

Mattheck, C., and H. Breloer. 1994. The Body Language of Trees. The Stationary Office, Norwich, U.K. 239 pp.

Mattheck, C., M. Teschner, and J. Schafer. 1997. Mechanical control of root growth: A computer simulation. Journal of Theoretical Biology 184:261-269.

Mickovski, S.B., and A.R. Ennos. 2003. Anchorage and asymmetry in the root system of Pinus peuce. Silva Fennica 37:161-173.

Mickovski, S.B., and R.A. Ennos. 2002. A morphological and mechanical study of the root system of suppressed crown Scots pine. TreesStructure and Function 16:274-280.

Miller, F.D., and D. Neely. 1993. The effect of trenching on growth and plant health of selected species of shade trees. Journal of Arboriculture 19:226-229.

O'Sullivan, M.F., and R.M. Ritchie. 1993. Tree stability in relation to cyclic loading. Forestry. 66:69-82.

Smiley, E.T. 2005. Root growth near vertical root barriers. Journal of Arboriculture 31:150-152.

Smiley, E.T., B.R. Fraedrich, and N. Hendrickson. 2002. Tree Risk Management. Bartlett Tree Expert Co., Charlotte, NC. 44 pp.

Smiley, E.T., A. Key, and C. Greco. 2000. Root barriers and windthrow potential. Journal of Arboriculture 26:213-217.

Smiley, E.T., T.R. Martin, and B.R. Fraedrich. 1998. Tree root failures. In Neely, D., and G.W. Watson (Eds.). The Landscape Below Ground II. Proceedings of an International Workshop on the Tree Root Development in Urban Soils. International Society of Arboriculture, Champaign, IL. 265 pp.

Stokes, A. 1999. Strain distribution during anchorage failure of Pinus pinaster at different ages and tree growth response to wind-induced root movement. Plant and Soil 217:17-27.

Stokes, A., J. Ball, A.H. Fitter, P. Brain, and M.P. Coutts. 1996. An experimental investigation of the resistance of model root systems to uprooting. Annals of Botany 78:415-421.

Stokes, A., and C. Mattheck. 1996. Variation of wood strength in tree roots. Journal of Experimental Botany 47:693-699.

Watson, G.W. 1988. Tree growth after trenching and compensatory crown pruning. Journal of Arboriculture 24:47-53.

\section{E. Thomas Smiley \\ Arboriculture Researcher \\ Bartlett Tree Research Laboratory \\ 13768 Hamilton Road \\ Charlotte, NC 28278, U.S. \\ tsmiley@Bartlettlab.com}

Résumé. Le but de cette étude était d'examiner deux types de taille des racines et de déterminer l'impact de la perte en racines sur la stabilité de l'arbre. Les troncs des arbres ont été tirés à un angle de $1^{\circ}$ de la verticale au moyen d'une force mesurée. Un tiers des arbres étudiés ont été tirés jusqu'au point de rupture afin de déterminer une corrélation 
entre une force de tirage de $1^{\circ}$ et une force de tirage jusqu'au point de rupture. Lorsque des coupes linéaires ont été faites au travers de la zone racinaire afin de simuler une tranchée de conduits souterrains, des variations mesurables dans la force ont été observées lorsque les coupes étaient faites à l'intérieur d'une zone correspondante à trois fois le diamètre du tronc; les forces étaient modifiées de 35\% lorsqu'une coupe tangentielle était faite au tronc. Lorsque des racines individuelles étaient coupées, la force était modifiée pour chacune des coupes de racines. Lorsqu'une racine seulement était coupée, la variation dans la force était de $12 \%$, et lorsque $50 \%$ des racines étaient coupées, la variation dans la force était de $30 \%$. Les tranchées linéaires devraient être gardées à une distance équivalente ou supérieure à trois fois le diamètre du tronc.

Zusammenfassung. Die Absicht dieser Studie lag in der Untersuchung von zwei Arten des Wurzelrückschnitts und der Bestimmung des Einflusses der Wurzelverletzung auf die Baumstabilität. Baumstämme wurden bis zu einem Winkel von 1 Grad vertikal mit kontrollierter Kraft gezogen. Ein Drittel der untersuchten Bäume wurde bis zum Baumversagen gezogen, um die Korrelation zwischen 1-Grad Zugkraft und totaler Bruchkraft zu bestimmen. Wenn in der Wurzelzone lineare Schnitte gemacht wurden, die Schachtbau simulieren sollten, wurden messbare Unterschiede in der Kraft festgestellt, wenn die Schnitte im Abstand von dreimal des Stammdurchmessers gemacht wurden, und die Kraft änderte sich um $35 \%$, wenn ein tangentialer Schnitt am Stammfuß gezogen wurde. Wenn eine Wurzel riss, änderte sich die Kraft um $12 \%$ und wenn $50 \%$ der Wurzeln verletzt wurden, veränderte sich Kraft um $30 \%$. Lineare Grabungen sollten in einem Abstand von wenigstens dreimal des Stammdurchmessers gehalten werden.

Resumen. El propósito de este estudio fue examinar dos tipos de poda de raíces y determinar el impacto de la corta de las raíces en la estabilidad del árbol. Los troncos de los árboles fueron tironeados a un ángulo de 1 grado de la vertical usando una fuerza registrada. Un tercio de los árboles estudiados fueron tironeados hasta el rompimiento para determinar la correlación entre 1 grado de fuerza y la fuerza de falla. Cuando los cortes fueron hechos a través de la zona de raíces, simulando excavaciones para servicios, se encontraron cambios cuando las cortas estuvieron dentro de tres veces el diámetro del tronco y la fuerza cambió en $35 \%$ cuando un corte tangencial fue hecho en el tronco. Cuando las raíces individuales fueron cortas severamente, la fuerza cambió con cada corte de raíz. Cuando una raíz fue cortada el cambio en fuerza fue $12 \%$ y cuando $50 \%$ de las raíces fueron cortadas la fuerza en cambio fue del $30 \%$. El zanjeo lineal deberá mantener una distancia igual o mayor a tres veces el diámetro del tronco. 